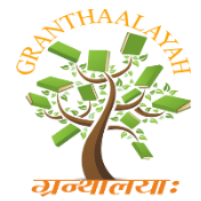

INTERNATIONAL JOURNAL OF RESEARCH GRANTHAALAYAH

A knowledge Repository

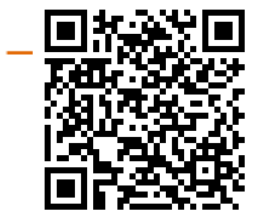

Management

\title{
THE EFFECT OF LEADERSHIP, JOB SATISFACTION AND ORGANIZATIONAL COMMITMENT ON EMPLOYEE PERFORMANCE AT RUMAH SAKIT UMUM DAERAH BESUKI SITUBONDO, INDONESIA
}

\author{
Amrozi 1, Zarah Puspitaningtyas ${ }^{1}$, Djoko Poernomo ${ }^{1}$ \\ ${ }^{1}$ University of Jember
}

\begin{abstract}
This study is to examine the influence of leadership, job satisfaction and organizational commitment on employee performance. Population in this research was the entire employees of Rumah Sakit Umum Daerah (RSUD) Besuki, Situbondo, Indonesia which was about 295 peoples. Then, the researcher applied probability random sampling technique to select 170 respondents as the sampling. The researcher analyzed the data by applying multiple linear regression method. The result shows that leadership and job satisfaction contribute positive and significant effect on employee performance, while organizational commitment has no effect on employee performance.

Keywords: Leadership; Job Satisfaction; Organizational Commitment; Employee Performance

Cite This Article: Amrozi, Zarah Puspitaningtyas, and Djoko Poernomo. (2018). "THE EFFECT OF LEADERSHIP, JOB SATISFACTION AND ORGANIZATIONAL COMMITMENT ON EMPLOYEE PERFORMANCE AT RUMAH SAKIT UMUM DAERAH BESUKI SITUBONDO, INDONESIA." International Journal of Research - Granthaalayah, 6(6), 322-334. https://doi.org/10.29121/granthaalayah.v6.i6.2018.1377.
\end{abstract}

\section{Introduction}

Hospital is a public organization that provides services. It should be able to create a situation and a condition that encourage and enable employees to develop skills optimally, especially in terms of job performance to provide excellent services to meet the needs and the growing demands of customers. Performance is the act of how employee performs his/her work or a process that is related to the assigned work. Mahsun (2014) argued that performance is a description of the level of achievement of the implementation of an activity in realizing the goals, goals, vision, and mission of the organization contained in the organization strategy.

In public organizations such as subordinate hospitals, work performance always depends on the leader. If the leadership does not exist among the leader and the absence of malfunction of the function appears, then, a very complex task cannot be done properly. An organization needs an effective leader who has the ability to influence the behavior of the members or subordinates. A 
leader will be recognized if s/he can influence and be able to direct his subordinates toward the goals of the organization.

An effective leader is a leader who is able to identify the important potential within an individual. Every individual has different needs and desires. Each individual has different skill levels as well. Leaders must understand the potential and problems that each individual has thoroughly. By doing this approach, the leader can apply all the rules and policies of the organization and delegate duties and responsibilities appropriately. This is in line with efforts to foster organizational commitment of an employee, so that a leader is able to improve employee job satisfaction and employee performance.

The previous studies have been debating the influence of leadership, job satisfaction and organizational commitment on employee performance. The study conducted by Yukl (1989) concludes that leadership has a positive and significant impact on employee performance. The study conducted by Kadir (2005) shows that organizational justice, organizational culture, salary satisfaction, organizational commitment have a positive effect on employee performance. Meanwhile, the study conducted by Sukmasari (2011) shows that leadership has no effect on employee performance. However, Sunarno (2015) in his study concluded that organizational commitment has no effect on the job performance of teachers.

According to the previous description, the researcher formulated following research problem:

1) Does leadership affect the performance of employees?

2) Does job satisfaction affect employee performance?

3) Does organizational commitment affect employee performance?

\section{Materials and Methods}

\section{Performance}

Etymologically, performance comes from the word performance (performance). As stated by Mangkunegara (2005) that the term performance comes from the word job performance or actual performance (actual work performance or achievement achieved by someone) is the job accomplishment in terms of quality and quantity achieved by an employee in performing their duties based on the responsibilities given to the employee.

Following description are the indicators to measure job performance according to Mathis and Jackson (2006):

1) Quantity: is the amount job output, the number of activity cycles completed by the employee, and the amount of activity conducted by an employee.

2) Quality: is measured from employee perceptions toward the quality of work produced by an employee and task perfection based on the skills and abilities of employees.

3) Punctuality: is measured from the employee's perception of an activity completed at the beginning until it is finished.

4) Attendance: attendance of employees either in the workplace, work, permit, or without information which entirely affect the performance of employees.

5) Teamwork: is a task and a job that has been set so as to achieve optimum usability. 


\section{Leadership}

House in Yukl (1989) says that leadership is the ability of individuals to influence, motivate, and make others able to contribute to the effectiveness and success of the organization. Based on the opinion House can be said that leadership is a way to influence and motivate others so that people will contribute to the success of the organization.

According to Wahjosumidjo (2007) leadership indicators are listed as follows:

1) Being fair: in the activities of an organization, a sense of togetherness among members is a must. Togetherness is a reflection of an essential agreement between employees and a leader in achieving organizational goals.

2) Suggestion: suggestion is an influence that can move the hearts of others. It is very important in maintaining and nurturing self-esteem and a sense of dedication, participation, and a sense of togetherness among employees.

3) Supporting objectives: the achievement of organizational goals is not automatically established, but it must be supported by leadership.

4) The catalyst: a leader acts as a catalyst. The leader always improves all existing human resources and raises the motivation.

5) Creating a sense of security: every leader is able to create a sense of security for his/her employee. Leaders must be able to maintain the positive feeling and optimism in order that the employee is able to face all problems, do duties well, and feel safe.

6) As the representative of the organization: a leader has an important role in all aspects of an organization. It means that the leader is a role model for the employee in terms of attitude and Excellency.

7) The source of inspiration: a leader must always be able to motivate the employee to achieve the goals of the organization by performing job effectively and efficiently.

8) Respectful: award is a gift for those who perform excellent performance. A leader is able to award the employee to motivate the employee in order that they can increase the job performance.

\section{Job Satisfaction}

Satisfaction is a psychological atmosphere about pleasant or unpleasant feelings about their work (Davis, Keith, 2001). Meanwhile Porter and Lawler in Bavendam (2000) explained that job satisfaction is an undimensional building, where a person has a general satisfaction or dissatisfaction with his work. Vroom as cited by Ahmad, MA Roshidi (1999) defines job satisfaction as a reference of an employee's effective orientation to their role in the current position he holds.

Indicators of job satisfaction according to Hasibuan (2009) cover six measurements, namely:

1) Fair and decent

2) Appropriate communication services

3) The duties

4) Atmosphere of work environment.

5) Tools that support the work performance

6) Leadership and attitude. 


\section{Organizational Commitment}

According to Wijono (2008), commitment is the determination to do something. A good commitment is a commitment that begins with the leadership. Meanwhile, according to Robbins (2001), an employee's commitment to an organization is a situation in which employees commits to one particular organization and its goals and intend to maintain its membership in the organization.

Allen and Meyer (1990) classify organizational commitment into three dimensions, namely:

1) Affective commitment (affective commitment) is the emotional involvement of workers to the organization. This commitment is influenced and / or developed when engagement in the organization proves to be a rewarding experience.

2) Continuous commitment (continuance commitment) is commitment involvement based on the costs incurred due to the release of workers from the organization. This commitment is influenced and / or developed when individuals invest.

3) Normative commitment (normative commitment) is the involvement of the workers feeling towards the tasks that exist in the organization. Normative commitment is influenced and / or developed as a result of the internalization of normative pressure to perform certain actions, and receives benefits that generate feelings of obligations to be reciprocated.

\section{Conceptual Framework}

Based on the above description, then the researcher compiled a framework of theoretical thinking that states the influence between the variables in this study. For the details, the theoretical framework is illustrated in the image below:

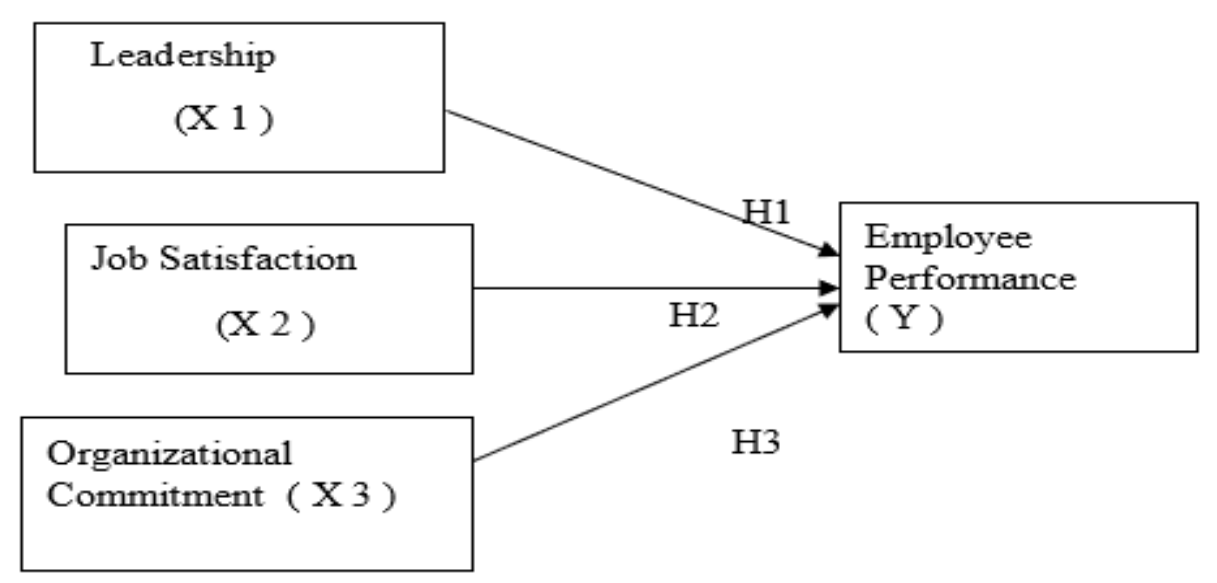

Conceptual Framework

\section{Hypothesis}

The researcher formulated hypothesis so that the researcher is able to conduct a research and discuss problem in this research very well. According to Sutrisno Hadi (1993), the hypothesis is a statement or temporary conclusion while the researcher figures out the final conclusion of the research. The hypotheses of this research are:

1) H1: Leadership affects employee performance

2) H2: Job satisfaction affects employee performance

3) H3: Organizational affects employee performance 


\section{Method}

\section{Population and Sample}

\section{Population}

Population is amount of all objects (units / individuals) whose characteristics are examined (Djarwanto and Pengestu, 1998). The population in this study was 295 employees at RSUD Besuki, Situbondo, Indonesia.

\section{Sample}

Sample, according to Indriantoro and Supomo (2004) is defined as part of the populations that will be studied, used to infer or describe the entire population. Selection of samples with appropriate methods can accurately describe actual population conditions and save research costs effectively. To determine the sample used in this study, the researchers applied following Slovin formula:

$n=\mathrm{N} /\left(1+\mathrm{N} \mathrm{e}^{2}\right)$

$=295 /(1+295 \times 0.052)=169.78$ H 170 respondents

Next how the selection of samples with random sampling technique based on the probability of each grouping based on the labor type in the hospital with the calculation as seen in table 3.1.

Table 3.1: Number of Respondents by Type of Labor at RSUD (Public Hospital) Besuki Situbondo, Indonesia

\begin{tabular}{|l|l|l|l|l|}
\hline No. & Types of & Population & Counts & Sample Number \\
\hline $\mathbf{1}$ & Medical / Doctor & 11 & $\begin{array}{l}11 \times 170 \\
295\end{array}$ & $6.3=6$ \\
\hline $\mathbf{2}$ & $\begin{array}{l}\text { Paramedics (Nurses and } \\
\text { midwives) }\end{array}$ & 136 & $\begin{array}{l}136 \times 170 \\
295\end{array}$ & $78.4=79$ \\
\hline $\mathbf{3}$ & Medical support & 19 & $\begin{array}{l}19 \times 170 \\
295\end{array}$ & $10.9=11$ \\
\hline $\mathbf{4}$ & Non medical & 129 & $\begin{array}{l}129 \times 170 \\
295\end{array}$ & $74.3=74$ \\
\hline & Total & 295 & & 170 \\
\hline
\end{tabular}

Source: Primary Data, 2017

\section{Analysis and Data Processing}

After data had been collected, the data is processed and analyzed to answer research questions in order to uncover certain social phenomena. Data analysis is the process of simplifying the data into a form that is easier to read and implement. The method chosen to analyze the data must be in accordance with the research pattern and the variables of the study. Accordingly, this research applied multiple linear regression analysis.

Multiple linear regression analysis is a linear relationship between two or more independent variables $\left(\mathrm{X}_{1}, \mathrm{X}_{2}, \ldots . \mathrm{X}_{\mathrm{n}}\right)$ with the dependent variable $(\mathrm{Y})$. This analysis is to know the direction of the relationship between independent variables and dependent variable whether each 
independent variable is positive or negative and to predict the value of the dependent variable whether the value of the independent variable increases or decreases.

This study analyzes the relationship of three independent variables and the dependent variable namely leadership variable $(\mathrm{X} 1)$, job satisfaction variables $\left(\mathrm{X}_{2)}\right.$ and organizational commitment variable $\left(\mathrm{X}_{3}\right)$ to variable employee performance $(\mathrm{Y})$.

\section{Classic Assumption Test}

Assumption test of the regression model is used to know whether the regression model is a good regression model or not (Ghozali, 2016). The classical assumption test conducted in this study is multicollinearity test, heteroscedasticity test, and normality test.

\section{Multiple Linear Regression Analysis}

Multiple linear regression analysis is used to determine how much influence the relationship of leadership variable (X1),job satisfaction (x2),organizational commitment $(\mathrm{X} 3)$, the dependent variable employee performance $(\mathrm{Y})$.

The regression equation in this study is:

$\mathrm{Y}=\beta_{1} \mathrm{X}_{1}+\beta_{2} \mathrm{X}_{2}+\beta_{3} \mathrm{X}_{3}+{ }^{2}$

\section{Description}

Y = Employee Performance

$\beta_{1} \quad=$ Regression coefficient of variable $X_{1}$ (Leadership)

$\mathrm{X}_{1} \quad=$ Leadership

$\beta_{2} \quad=$ Regression coefficient of variable $\mathrm{X}_{2}$ (Job satisfaction)

$\mathrm{X}_{2} \quad=$ Job satisfaction

$\beta_{3}=$ Regression coefficient of variable $\mathrm{X}_{3}$ (Organizational commitment)

$\mathrm{X}_{3}=$ Organizational commitment

$\mathrm{e} \quad=$ Standard error

\section{Results and Discussions}

\section{Classical Assumption Test}

Ghozali (2016), the classical assumption test is useful to know whether or not the deviation of classical assumption to the multiple linear regression equation used. The classical assumption test used in this research was normality test, multicollinearity test and heteroscedasticity test.

\section{Normality Test}

The test is used to identify whether residual variable in the model has a normal distribution. Ghozali (2016). Normality test conducted in this research was Kolmogorov-Smirnov model testing. According to Sujarweni (2015), states that data is classified as normal if the value of significance $>0.05$. The results of the normality test of this study can be seen in Table 4.3 
Table 4.3 The Result of Normality Test

\begin{tabular}{|l|l|l|}
\hline Variable & $\begin{array}{l}\text { Significance } \begin{array}{r}\text { Value } \\
\text { Kolmogorov-Smirnov }\end{array} \\
\text { Leadership }(\mathrm{X} 1)\end{array}$ & Description \\
\hline Job Satisfaction $(\mathrm{X} 2)$ & 0.200 & Normal \\
\hline Commitment $(\mathrm{X} 3)$ & 0.054 & Normal \\
\hline Performance $(\mathrm{X} 4)$ & 0.064 & Normal \\
\hline
\end{tabular}

Source: Primary data, 2018.

Based on Table 4.3 it can be seen that all the data on the variables in this study are normally distributed because the whole value of Kolmogorov-Smirnov is more than 0.05. It concludes that all data variables are normally distributed.

\section{Multicolinearity Test}

This test is to determine independent variables that have similarities with other independent variables in one model. Multicollinearity detection in a model can be seen from the value of variance inflation factor (VIF) and value tolerance. If the value of variance inflation factor (VIF) is not more than 10 and the value of tolerance is not less than 0.1 , then it can be said that it is free from multicollinearity (Ghozali, 2016). The results of the test multikolinieritas can be seen in Table 4.4

Table 4.4: The Results of Multicolinearity Test

\begin{tabular}{|l|l|l|l|}
\hline Variable & Value Tolerance & Value VIF & Description \\
\hline Leadership (X1) & 0.351 & 2.848 & Non multicoloniarity \\
\hline Job Satisfaction (X2) & 0.511 & 1.957 & Non multicoloniarity \\
\hline Organizational Commitment (X3) & 0.506 & 1.976 & Non multicoloniarity \\
\hline
\end{tabular}

Source: Primary Data, 2018.

Multicollinearity test results show that all variables have tolerance value $>0.1$ and VIF value $<10$. Accordingly, it concludes that there is no correlation between independent variables. In other words, all the variables are free from multicollinearity.

\section{Heteroscedasticity Test}

The test is to test existence of variant inequality of the residual of another observation in a regression model - a good regression model should be free of heteroscedasticity problem. Sujarweni (2015) stated that a good regression model is free of heteroscedasticity with a significance value greater than 0.05 . The result of heteroscedasticity test can be seen in Table 4.5.

Table 4.5: The Results of Heteroscedasticity Test

\begin{tabular}{|l|l|}
\hline Variable & Significance Values \\
\hline Leadership(X1) & 0.802 \\
\hline Job Satisfaction (X2) & 0.583 \\
\hline Organizational Commitment $(\mathrm{X} 3)$ & 0.401 \\
\hline
\end{tabular}

Source: Primary data, 2018. 
Based on Table 4.5 heteroscedasticity test results indicate that all variables have a significance value greater than 0,05 . It means that the regression model is free from heteroscedasticity.

\section{Multiple Linear Regression Test}

Linear regression is a test that is used to analyze the effect of independent variables (Leadership, Job Satisfaction and Organizational Commitment) on the dependent variable that is Employee Performance employee of RSUD Besuki, Situbondo, Indonesia. The results of multiple linear regression test in this study can be seen in Table 4.6.

Table 4.6: The Results of Multiple Linear Regression

\begin{tabular}{|l|l|l|}
\hline \multirow{2}{*}{ Model } & \multicolumn{2}{|l|}{ Unstandardized Coefficients } \\
\cline { 2 - 3 } & B & Std. Error \\
\hline (constant) & 4.426 & 1.667 \\
\hline Leadership (X1) & 0.209 & 0.019 \\
\hline Job Satisfaction (X2) & 0,523 & 0,035 \\
\hline Organizational Commitment (X3) & -0.044 & 0.050 \\
\hline
\end{tabular}

Source: Primary data, 2018

Based on the table, the multiple linear regression equation are as follows:

$\mathrm{Y}=4,426+0,209 \mathrm{X}_{1}+0,523 \mathrm{X}_{2}-0,044 \mathrm{X}_{3}+\mathrm{e}$

Description:

$\mathrm{Y} \quad=$ Performance

$\mathrm{X}_{1} \quad=$ Leadership

$\mathrm{X}_{2} \quad=$ Job Satisfaction

$\mathrm{X}_{3} \quad=$ Organizational Commitment

The descriptions of the regression equation in Table 4.6 are explained as follows:

1) Constant value 4,426 means that if $\left(X_{1}, X_{2}\right.$, and $\left.X_{3}\right)$ is assumed to be fixed or 0 , then Performance value will be 4,426 .

2) Regression coefficient $X_{1}$ (Price) from multiple linear calculation was from coefficient value 0,209. If Leadership increases by one unit, then Performance will increase by 0.209. Coefficient of positive value $(+)$ means that there is a positive relationship between Leadership variables $\left(\mathrm{X}_{1}\right)$ and Performance variable $(\mathrm{Y})$. With error standard of 0,019 - it means error rate of Leadership variable that predict Performance is 0,019.

3) Regression coefficient $X_{2}$ (Job Satisfaction) from multiple linear calculation resulted coefficient value 0,523. If the Job Satisfaction is one unit, then Performance will increase by 0,523 . The coefficient is positive $(+)$ means that there is a positive relationship between job satisfaction variables $\left(\mathrm{X}_{2}\right)$ and the performance variable $(\mathrm{Y})$. With error standard of 0.035 - it means the error rate of Job Satisfaction that Predict Performance is 0.035 .

4) Regression coefficient $X_{3}$ (Organizational Commitment) from multiple linear calculation had coefficient value -0,044. If Organizational Commitment increases by one unit, then Performance will decrease by -0.044 . The coefficient is negative (-). It means that there is a positive relationship between the variables of Organizational Commitment $\left(\mathrm{X}_{3)}\right.$ and performance variable (Y). The error standard is 0.050 - it means that the variable error level of Organizational Commitment that predicts Performance is 0.050 . 


\section{Test $\mathbf{t}$}

Test $\mathrm{t}$ is used to figure out how far the influence of independent variables individually to the dependent variable. The testing is executed by using significance level $0,05(\mathrm{a}=5 \%)$. If $\mathrm{t}_{\text {arithmetic }}>$ from $t_{\text {table }}$ or significance value $<5 \%(0.05)$. It means that $\mathrm{H}_{0}$ is rejected - there is significant influence between independent variable (Leadership, Job Satisfaction and Organizational Commitment) on dependent variable (Performance) Partially. Meanwhile, if the significance level of $<0.05$ and $\mathrm{t}_{\mathrm{t}}<\mathrm{t}_{\text {table }}$ then $\left(\mathrm{H}_{1}, \mathrm{H}_{2}, \mathrm{H}_{3}\right.$ and $\left.\mathrm{H}_{4}\right)$ is rejected and $\mathrm{H}_{0}$ accepted. The T-test results can be seen in Table 4.7 .

Table 4.7: The Result of T-Test (Partially)

\begin{tabular}{|l|l|l|l|l|}
\hline Variable & $\boldsymbol{t}$ & $\boldsymbol{t}_{\text {table }}$ & Value significance & Description \\
\hline Leadership (X1) & 10.833 & 1.974 & 0.000 & Significant \\
\hline Job Satisfaction (X2) & 14.944 & 1.974 & 0.000 & Significant \\
\hline Organizational Commitment (X3) &,- 884 & 1.974 & 0.378 & Not significant \\
\hline
\end{tabular}

Source: Primary data, 2018.

Decision-making according to Sujarweni (2015):

1) $\mathrm{H}_{0}$ is accepted if $\mathrm{t}_{\text {arithmetic }}<\mathrm{t}_{\text {table }}(\mathrm{df}=\mathrm{n}-1$; double-sided $(0.025))$ and significance value $>$ 0,05 .

2) $\mathrm{H}_{1 \text { is }}$ accepted if $\mathrm{t}_{\text {count }}>\mathrm{t}_{\text {table }}(\mathrm{df}=\mathrm{n}-1$, double side $(0,025))$ and significance value $<0,05$.

3) $\mathrm{H}_{2}$ is accepted if $\mathrm{t}_{\text {count }}>\mathrm{t}_{\text {table }}(\mathrm{df}=\mathrm{n}-1$, double side $(0,025))$ and significance value $<0,05$.

4) $\mathrm{H}_{3}$ accepted if $\mathrm{f}_{\mathrm{t}} \mathrm{t}_{\text {table }}(\mathrm{df}=\mathrm{n}-1$; the two sides $(0.025))$ and the significance value $<0.05$.

5) $\mathrm{H}_{4}$ is accepted if $\mathrm{t}_{\text {count }}>\mathrm{t}_{\text {table }}(\mathrm{df}=\mathrm{n}-1$, double side $(0,025))$ and significance value $<0,05$. $\mathrm{t}$ test results in Table 4.7 can be explained as follows:

\section{Hypothesis Test $\mathrm{H}_{1}$}

According to Ghozali (2016), if $t_{\text {counted }}>t_{\text {table }}$ and significance value $<0.05$, it has a significant effect. The results of the $t$ test were value of $t_{\text {counted }} 10.833>t_{\text {table }} 1.974$ and leadership variable significance value was $0.000<0.05$. These results indicate that leadership has a significant effect on the performance of employees at the RSUD Besuki Situbondo, Indonesia. $\mathrm{So} \mathrm{H}_{0}$ is rejected and $\mathrm{H}_{1}$ is is accepted.

These results are in line with the studies of Heryanto (2004) and proves that leadership has a positive and significant impact on employee performance. This positive relation shows the influence of leadership on employee performance.

\section{Hypothesis Test $\mathrm{H}_{2}$}

According to Ghozali (2016), if $t_{\text {counted }}>t_{\text {table }}$ and significance value $<0.05$, it has a significant effect. The results of the $t$ test was value $t_{\text {counted }} 11.944>t_{\text {table }} 1.974$, and the value of job satisfaction variable significance was $0.000<0.05$. These results indicate that variable of job satisfaction has a significant effect on the performance of employees of RSUD Besuki Situbondo, Indonesia. Then $\mathrm{H}_{0}$ is rejected and $\mathrm{H}_{2}$ is accepted. The results are in line with the study that has been done by Devi (2009) which proves that the variable of job satisfaction and motivation shows a significant positive impact on employee performance. 


\section{Hypothesis Test $\mathrm{H}_{3}$}

According to Ghozali (2016), if $t_{\text {counted }}>t_{\text {table }}$ and significance value $<0.05$, it has a significant effect. The results of the $t$ test showed value $t_{\text {counted }}-0.884<t_{\text {table }} 1.984$, and the value of variable significance organizational commitment was $0.378>0.05$. These results indicate that the organizational commitment variable has no effect on the performance of employees of RSUD Besuki Situbondo, Indonesia. So $\mathrm{H}_{0}$ is accepted and $\mathrm{H}_{3}$ is rejected. The results are in line with a study that has been done by Sunarno (2015) which provees that organizational commitment has no effect on the performance of teachers.

\section{Discussion}

\section{The Influence of Leadership on Employee Performance RSUD (Public Hospital) Besuki}

In table $4.7 \mathrm{t}$ test results has been analyzed by applying partial correlation to figure out the correlation between leadership variables $\left(\mathrm{X}_{1}\right)$ and the performance $(\mathrm{Y})$. The test shows significance value $=0,000$. This value shows a positive relationship between $\left(\mathrm{X}_{1}\right)$ and $(\mathrm{Y})$. The positive meaning here is a direct relationship between leadership variables with performance - It means that if the value of leadership goes up, then the performance will rise significantly. The indicators used in leadership measurement are 8 (eight) indicators that are beng fair employee, giving suggestions, supporting the goals achievement, being a catalyst, building secure sense, being a representative of the organization, being a source of inspiration, and being respectful.

Among 8 indicators, (a leder) who always supports the goal achievement of the organization influencees employee performance improvement at the best. In addition, respondent has following perceptions: the hospital leader is a highly initiative person in giving exellent idea to improve employee performance. Furthermore, respondents also thought that the leader / director execute a good approach to the employee or to cross-sector to improve the job perfromance. The leader also supports good ideas / initiatives from employee to build a good organization. For that reason, the leader should always maintan a good atmosphere to improve the employees performance in the public hospital.

The lowest indicator of leadership according to respondents is the source of inspiration. It means that the head of the hospital during this time often look less tidy and less attractive. The appearance of the leader lead to the lack of trust whenever s/he delivers speech. In additon, the respondents explained that the leader also rarely performs a good communication among the employees. This, of course, contributes the low employees performance in the hospital. In other word, applying a good communicaton principle (good language and politeness) is important for the leader so that the leader becomes a role model in communication for the employee s/he leads.

These results are in line with previous studies by Heryanto (2004) who proved that leadership has a positive and significant impact on employee performance. This positive influence indicates a direct influence between leadership and employee performance, or in other words, a good leadership leads to the high employee performance. Whereas, this significant influence shows that leadership has a significant effect on employee performance.

Influence of Job Satisfaction on Employee Performance of RSUD (Public Hospital) Besuki Situbondo, Indonesia 
The result of hypothesis test in table 4.7 has been be analyzed by applying partial correlation to find out the correlation between job satisfaction variable $\left(\mathrm{X}_{2}\right)$ and performance variable $(\mathrm{Y})$. The result shows significance value $=0,000$. This value indicates a positive relationship between $\left(\mathrm{X}_{2}\right)$ and (Y). The positive meaning here is a direct relationship between job satisfaction variables and employee performance - it means that that if the value of job satisfaction increases then the performance of employees will rise significantly. There are 6 (six) indicators used in the measurement of job satisfaction which are: fair and good service, good communication, work capacity, working environment atmosphere, tools for work performance, and attitude and leadership.

The most influencing indicators on the employee performance is the atmosphere of work environment. The result of the questioner shows that the employee always works based on the job description assigned by the leader and the ability. In addition, the employee thought that the employee feel a pleasure in the work environment and focus the assigned jobs. This pleasant feeling contributeto the employee performance improvement.

The lowest indicator of job satisfaction that can cause the low performance of employees in the hospital according to the respondents obtained is tools that support the implementation of work. In addition, the failrly-distributed services plays role in leading to the low employee performance. Most hospital employees feel that the existing facilities and infrastructure does not meet the standard. This is caused by the newly-established pblic hospital - RSUD (public hospital) Besuki, Situbondo was built in 2013 so it is still in the process of improving and refining infrastructure. Job stasfaction becomes a sensitive issue for employee. According to the questioner, services distribution among the employee is less fair that the employee feel uncomfortable in performing the job. These results are in line with previous studies by Devi (2009) which proves that the variable of job satisfaction and motivation showed a significant positive effect on employee performance.

\section{Influence of Organizational Commitment on Employee Performance hospitals Besuki Situbondo, Indonesia}

Based on the results of hypothesis testing in Table 4.7 can be seen the correlations partially between the variables of organizational commitment $(\mathrm{X} 3)$ and a performance variable (Y). The result of the test shows significance value $=0.378$. This value shows a negative relationship between $\left(\mathrm{X}_{3}\right)$ and $(\mathrm{Y})$. This means that organizational commitment is not proven to affect the performance of employees at RSUD Besuki. There are three (3) indicators Indicators used in the measurement of organizational commitment which are: affective commitment (affective commitment), continuance commitment (continuance commitment), and normative commitment (normative commitment).

The result of the questionaire illustrate that most of the hospital employees have not been able to feel that the hospital is their second home. They cannot feel that the hospital is their own that must be maintained, guarded and strived to be a better hospital in the future. Even, some employees do not feel to loose if there is a better offer in the other workplace.

This is in line with the data of RSUD Besuki RSUD Besuki that the authors observed. The data was about the tilazation of public hospital in 2016 - the data showed that the number of Bed 
Occupancy Rate (BOR) that is the percentage of bed usage in a certain time unit which is only $60.75 \%$ (Health Department Standard ,> 75\%), Average Length Of Stay (ALOS) is the average length of treatment of a patient 3 days (Health Department Standard 5 - 9 days) while the number of referral of inpatients is about $15.6 \%$ (Health Department Standard <12\% ).

The reason of those facts is that the status of the employee. The number of respondents whose employment status is probation is about 105 people (61.77\%). They are not paid monthly, but they are paid with an uncertaint amount of fee for their services. In addition, the regulation rules the employess that they are not allowed to demand themselves to be a civil servant and demand a monthly salary. Besides, the employees only hire for a year and it is automatically extended if they are needed. The results are in line with previous studies by Sunarno (2015) which proves that organizational commitment is not proven to affect teacher performance.

\section{Conclusions and Recommendations}

\section{Conclusions}

Based on the empirical findings, it can be concluded that:

1) The result of the hypothesis test proves that leadership variables have a positive and significant impact on employee performance at RSUD Besuki. The calculation of data analysis results significance value of $0.000<0.05$. So it can be concluded that $\mathrm{H}_{0}$ is rejected and $\mathrm{H}_{1}$ accepted.

2) The result of hhypothesis test proves that job satisfaction variable has a positive and significant impact on employee performance at RSUD Besuki. The calculation of data analysis results significance value of $0.000<0.05$. So it can be concluded that $\mathrm{H}_{0}$ is rejected and $\mathrm{H}_{2}$ is accepted.

3) The result of hhypothesis test proves that organizational commitment variable has no effect on employee performance RSUD Besuki. Calculation result of data analysis results significance value equal to $0,378>0,05$. So it can be concluded that $\mathrm{H}_{0}$ is accepted and $\mathrm{H}_{3}$ is rejected.

\section{Recommendations}

Based on the data, the respondents expect equality and justice for the employee. In the futere, the employee look forwards that The leader does not differentiate one another in the term of job distribution and salary.

A Leader and stake holders of the public hospital is expected to improve the communication among the employees so that the intimacy and togetherness between the leader and employees are built very well. If the leader is able to maintain a family atmoshperein the public hospital, s/he will enhance the emplpoyee performance that lead to customer satisfaction satisfaction. In other words, RSUD Besuki Situbondo, Indonesia is optimally utilixed by the surrounding community.

Last, but not least, the researcher expects that employee is able to improve performance, promote professionalism, have professional characteristics that work and provide service in public hospitals whether doctors, nurses, midwives and others. The better performance will lead to customer satisfacton which then might make RSUD Besuki memorable among the patient in terms of goodservice, communication, etc. 


\section{References}

[1] Mahsun. 2014, Teks Dalam Pembelajaran Bahasa Indonesia Kurikulum 2013.Jakarta; PT Raja Grafindo Persada.

[2] Yukl, Gary A, 1989, Managerial Leadership: A Review of Theory and Research, Journal of Management, Vol 15, No.2, 251-289.

[3] [3] Kadir, A. 2005, Pengaruh Keadilan Organisasi dan Budaya Organisasi terhadap Kepuasan Gaji, Komitmen Organisasi dan Kinerja, Jurnal Keuangan dan Perbankan, Surabaya.

[4] Sukmasari, H. 2011. Pengaruh Kepemimpinan Motivasi Intensif Lingkungan Kerja dan Kepuasan Kerja terhadap Kinerja Pegawai Dinas Pengelolaan Keuangan dan Aset Daerah Kota semarang. Masters Thesis, Universitas Dian Nuswantoro.

[5] Sunarno, 2015. Hubungan Pelaksanaan Supervisi, Budaya Sekolah, Semangat Kerja dan Motivasi Kerja dengan Kinerja Guru Pendidikan Jasmani Pada Sekolah Dasar Negri di Kalimantan Selatan, Disertasi Program Studi manajemen Pendidikan Pasca Sarjana Universitas Negri Malang

[6] Mangkunegara, P. Anwar. 2005. Manajemen Sumber Daya Manusia cetakan ke-3. Bandung: PT. Remaja Rosdakarya

[7] Mathis, Robert L and Jackson, John H, 2006, Human Resource Managemen: Manajemen Sumber Daya manusia, (terjemahan : Dian angelia), Salemba Empat, Jakarta.

[8] Wahjosumidjo, 2007. Teori Kepemimpinan dan Dasar Dasar Manajemen, Lembaga Administrasi Negara.

[9] Davis, Keith and John W. Newstroom. 2001. Perilaku dalam Organisasi, Jilid I Edisi Ke enam Alih Bahasa: Agus Dharma. PT.Erlangga. Jakarta.

[10] Bavendam, J. 2000. How Do you Manage turnover? in a time of line Orgazisation and Dwindiing pools of experienced new hires. J Spesial Report, Vol 3. Bavendam Riesearch Incoporeted, Mercer Island.

[11] Roshidi, Ahmad. 1999. Pengaruh Iklim Organisasi Terhadap Kepuasan kerja Guru Sekolah menengah: Kajian Kes di Daerah Padang Terap Kedah. Tesis Sarjana Sains fakulti Sains Kognitif dan Pembangunan Manusia, Universiti Malaysia Serawak.

[12] Hasibuan, M. 2009. Organisasi dan Motivasi. Jakarta: Bumi Aksara

[13] Wijono, D. 2008. Manajemen Mutu Rumah Sakit dan Kepuasan Pasien, Prinsip dan Praktek CV. Duta Prima Airlangga. Surabaya.

[14] Robbins, Stephen P. 2001. Organizational Behavior. Upper Saddle River. New Jersey: Prentice Hall Inc. Robbins

[15] Allen, Natalie J and Meyer, John P, 1990, The Measurement and Antecedents Of Affective, Countinuance And Normative Commitment To Organization, Journal of Occupational Psychology, 63, 1-18.

[16] Sutrisno Hadi. 1993.Metodologi Research.Jilid III.Yogyakarta.Andi Offset.

[17] Djarwanto, PS.dan Subagyo Pangestu. 1998, Statistik Induktif, BPFE, Jakarta.

[18] Indriantoro, N dan B. Supomo. 2004. Metode Penelitian Bisnis Untuk Akuntansi Dan Manajemen. Edisi Pertama, Yogyakarta: BPFE

[19] [19] Ghozali,I. ( 2016). Aplikasi Analisis Multivariate dengan Program IBM SPSS 23, edisi ke - 8. Badan Penerbit Universitas Diponegoro, Semarang.

[20] Sujarweni,V. 2015, SPSS Untuk Penelitian, Pustaka Baru Press. Yogjakarta.

[21] Heryanto, Ari.2004: Pengaruh Gaya Kepemimpinan Terhadap Kinerja Karyawan Perusahaan Motivasi sebagai Faktor Pemodernisasi. Surakarta: FE UNS

[22] Devi, Eva Kris Diana.2009, Analisis Pengaruh Kepuasan Kerja dan Motivasi Terhadap Kinerja dengan Komitmen Organisasional Sebagai Variabel Intervening (Studi pada Karyawan Outsourcing PT SemeruKarya Buana Semarang), Semarang, Tesis Program Pasca Sarjana UNDIP.

*Corresponding author.

E-mail address: zarah@ unej.ac.id 